\title{
Miraculous Rhetoric: The Relationship between Rhetoric and Miracles in the York 'Entry into Jerusalem'
}

The York 'Entry into Jerusalem' presents some striking commentaries on rhetoric, reason, and a community's efforts to engage in its faith. ${ }^{1}$ Scholars have focused on many aspects of the play, including its audience, sources, staging techniques, and the devotional and political aspects of its dialogue. ${ }^{2}$ They have not, however, examined the relationship between the fictional townspeople's long deliberations concerning their belief in Jesus, and the ultimate confirmation of that belief that results from seeing Jesus in the flesh and witnessing his spectacular healing miracles. This article examines the varying levels of certainty associated with verbal rhetoric and miracles, for both are means through which the play transmits and affirms the Christian faith. Throughout their deliberations, the characters call attention to the features of an argument that make it persuasive, frequently couching their assessment in language that skirts the boundaries between logical and rhetorical discourse. After approving of one another's arguments about Jesus's importance, the townspeople resolve to meet him and subsequently witness his public forgiveness of a penitent man, and his restoration of sight to a blind man (297), and soundness of body to a lame man (385). After these miracles, all of the characters praise Jesus with epideictic lyrics that both recapitulate and add rhetorical and conceptual complexity to the earlier discussions of Jesus's significance. ${ }^{3}$ Emphasizing the importance of the characters' rhetorical interactions and investment, the York 'Entry' depicts the relationship between rhetoric and miracles differently from depictions in other biblical plays. ${ }^{4}$ While other plays appear to subordinate the role of human speech in exploring or conveying religious truths, ${ }^{5}$ the York 'Entry' privileges rhetoric as the primary catalyst for the characters' encounter with Jesus, and affirms humanity's efforts to engage rhetorically with the tenets of its faith. Rhetorical interaction eventually leads the faithful, like the fictional townspeople of Jerusalem, to a literal and figurative encounter with the divine. 
Building upon Wayne Narey's assertion that the biblical plays meditate upon 'humanity's in-between state of quotidian doubts and eternal verities', ${ }^{6}$ I argue that the York playwright juxtaposes overt references to verbal persuasion with depictions of miracles to highlight the differences between the uncertainty of his audience's world and the miraculous certainty of the biblical narrative performed before them. ${ }^{7}$ While I do not wish to minimize the belief held by many people, medieval and modern, that eternal truths exist or that miracles happen every day, ${ }^{8}$ such spectacular affirmations of the Christian faith as Jesus himself walking down the street, healing the sick, raising the dead, and forgiving sins are difficult to reconcile with the ordinary world of which the medieval audience was a part. While the audience might indeed believe miracles to be possible, they likely did not witness such definitive confirmations of their faith. ${ }^{9}$ To compensate for the improbability of these public miraculous affirmations within the audience's everyday lives, the playwright offers the verbal interactions of the faithful community, for in these exchanges the community transmits and affirms the tenets of its faith. Within these interactions the playwright explores the varying levels of certainty inherent in two types of argument identified in the rhetorical tradition: those that are 'readily believable' to an audience, and those that are necessarily and demonstrably true. ${ }^{10}$ The former type of argument most often appears in the York 'Entry' as the enthymematic articulation of beliefs shared between a speaker and his audience, ${ }^{11}$ while the latter appears only as the definitive proof of Christ's presence and miracles. In a world where the deity does not walk the streets regularly and the average person cannot articulate his or her faith with demonstrable certainty, the playwright advocates for a community's awareness of and skill in the rhetorical promotion of its faith. A community's verbal promotion and affirmation of its beliefs - its participation in what James J. Murphy identifies as the 'corporate rhetorical tradition' 12 — can lead its people to experience certainty in their faith without demonstrable proof. Just as verbal interactions lead the fictional people of Jerusalem to a physical meeting with Jesus, so too can the medieval audience's active rhetorical engagement with the tenets of its faith lead it, literally and figuratively, to Christ.

The playwright establishes as valid rhetorical proof the communal affirmations of belief early in the dramatic action, when the apostles Peter and Phillip encounter a 'Janitor' or Porter of the town, while they attempt to procure the donkey on which Jesus will ride into the city. The Porter demands that the apostles explain why they are taking the donkey and instructs them to make plain: 
To what intente firste shall yoe saye,

And than I graunte what yoe will crave

Be gode resoune.

With this demand, the Porter establishes what will be for the playwright the proper burden of proof for arguments made in the rest of the play. In response to the Porter's demand that they present their case 'rationally', ${ }^{13}$ the apostles make astonishing claims. In addition to telling the Porter Jesus's name and ancestral home, they assert that he is the eternal King of Israel, sinless, both human and divine (80-3). The only support for their arguments is that 'Pis trist wele we' (84): that they have faith in these claims. ${ }^{14}$ The Porter replies that he has heard of Jesus (85) and asks for no more reasoned justification for the apostles' actions. On the surface the Porter's demand for 'good reason' is not as stringent as it first would appear, and apparently the playwright alludes to the concept of strict rationality only to undercut it by accepting arguments that are 'readily believable', or those 'to which agreement is spontaneously and willingly given, so that they are agreed to as soon as they are heard'. ${ }^{15}$ The Porter's speedy acquiescence encourages the audience to recognize that 'good reason' refers in this context to the articulation of a shared system of belief. ${ }^{16}$ Even though the apostles do not supply any 'good reasoning' in the logical sense, the communal approval of Jesus's status is the only reason the Porter needs.

The Porter's response illustrates what I describe as a rhetorical chain reaction, in which one person's zealous efforts to spread Jesus's message yield the same vigour in his audience. The Porter is quick to assert his belief that Jesus is ruler of the world and shaper of land and sea (113-14) and affirms that he will proclaim the news of Jesus's arrival until every citizen has heard it (101-2). Switching his vocation from a mere caretaker to Jesus's preacher and herald, the Porter, like many characters in the play, evolves from student to teacher. In so doing, the characters fulfill what Murphy recognizes as Christians' 'divine responsibility' to be rhetors themselves. ${ }^{17}$ In addition to spreading the message of Jesus's ministry itself, the apostles have successfully communicated to the Porter their eagerness to spread the Christian message. Both the message and the vigour behind it survive undiminished in the Porter, and both will be transmitted in the same manner to the townspeople.

The Porter fulfills his new obligation by resolving to inform the city's burgesses. Approaching them with the news, he states: 
Sirs, novelté I can 3ou telle

And triste pame fully as for trewe:

Her comes of kynde of Israell

Att hand pe prophette called Jesu,

Lo, pis same day,

Rydand on an asse. Pis tydandis newe

Consayue 3e may.

The Porter wants the burgesses to believe, as he does, that the man entering the city is a great prophet of Israel. He refers to his faith in Jesus's status by using the word 'trist', the exact term the apostles used to motivate him (84). In so doing, he establishes a speaker's faith in his message as the primary justification for a sound argument. The Porter's claims that the information is both 'novelté' and 'newe' are ironic commentaries on both the play and the spreading of the Christian message. The Porter's message is most certainly not 'novelté' or 'newe' to the York audience; in fact his message is one of the commonly accepted building blocks on which medieval English society is based. The York audience is supposed to recognize the familiarity of the message, yet it is encouraged to affirm and transmit its beliefs with a zeal similar to that exhibited by the fictional people of Jerusalem. ${ }^{18}$

The way the burgesses exemplify the corporate rhetorical tradition is especially interesting, for while they agree immediately with the Porter's assertions of Jesus's greatness, they discuss for nearly 150 lines whether or not to welcome him to the city. During this council the characters refer to and evaluate each other's arguments, often alluding to the arguments' sound 'reasoning'. The protracted debate appears to be ironic, especially given the Porter's confidence that he can motivate the burgesses 'withoute debate' (109). Yet in a way, the Porter's prediction is accurate, for the burgesses' speedy agreement on the proper course of action negates the concept of debate. The playwright prolongs the burgesses' dialogue to undercut his characters' preoccupation with reason and debate, thus showing that matters of faith have little to do with such discourse. The burgesses instead use other forms of argument, most notably narration, repetition, and appeals to commonly held beliefs. For the playwright, these arguments and the belief they inspire are 'reason' enough to lead the burgesses and the York audience to Jesus, and therefore, salvation.

The playwright continues to emphasize the communal approval of narrative by depicting the city's burgesses presenting stories of Jesus's preaching 
at the Temple (141-4) and tales of his knowledge of Mosaic Law (148-59) as 'evidence' that he is the messiah. The Second Burgess, who is actually the first one to respond to the Porter's claims, calls attention to the communal transmission of Jesus's message. He inquires:

And is pat prophette Jesu nere?

Off hym I haue heryde grete ferlis tolde.

He dois grete wounderes in contrees sere,

He helys pe seke, both 3onge and olde,

And pe blynde giffis pam per sight.

By referencing these 'grete ferlis' (128), marvelous stories of Jesus's miracles, the Second Burgess acknowledges that for many, the York audience included, knowledge of Christ's greatness comes most frequently from verbal accounts of miracles, and not through the immediate witnessing of miracles themselves. The second-hand nature of the information does not dissuade the Second Burgess, for while he may have heard these stories through the corporate rhetorical process, he believes them without a doubt and speaks of them as if there were no intermediary communicating the story to him. His assertions shift from 'I have heard of him performing miracles', to 'he does great wonders, healing the sick, and giving sight to the blind'. The move from storytelling to certainty is seamless. The Second Burgess's belief does not simply evoke the lesson of the 'Doubting Thomas' episode: 'blessed are they that have not seen, and have believed'. ${ }^{19}$ Rather, it shows that the people of a bustling populace frequently must rely on each other's accounts of such spectacular deeds, and not on directly witnessing the deeds themselves. Although Jesus does not walk the streets every day, a believer certainly can hear commonly accepted stories of his miracles. When he does hear these stories, the believer must reach the same level of certainty about his faith as he would if he were to witness a miracle affirming it. The First Burgess underscores this emphasis on the communal, verbal affirmation of faith when he praises the solid 'resoune' of the arguments that motivate him, reason against which he 'will no3t plete' (176). Much like the Second Burgess, the First arrives at a level of certainty based solely on the claims of his interlocutors: 'For wele I wote oure kyng he is' (177; emphasis mine). He will not debate these claims, and anyone who disagrees with this conclusion 'is noyot wise, he dose amys' (179). He agrees with the arguments not because they are demonstrably necessary, but because they use 'ensampelys' (170) that are consistent with the beliefs that he and his community already 
share. The burgesses decide to see Jesus because they have judged as acceptable their arguments for his status as their king and messiah.

The deliberations lead Burgesses Three, Four, and Five each to declare of Jesus: 'Oure kyng is he' $(224,225,238)$. They assert this without doubt, with only the support of their community members' accounts of Jesus's actions. The Seventh Burgess assesses their assertions not as statements of belief, but as rational arguments:

Of youre clene witte and youre consayte

I am full gladde in harte and pought,

And hym to mete withouten latt

I am redy, and feyne will noght [go],

Bot with 3ou same.

(246-50; brackets mine)

The Seventh Burgess will not argue with what he calls his fellows' clear reason, or their 'clene witte'. ${ }^{20}$ Once again the playwright emphasizes conventional notions of reason only to undercut them. Such reason, and the logical certainty that accompanies it, may not be the foundation of evangelizing rhetoric, but the repeated affirmation of a shared belief will be enough to move people toward a direct meeting with Christ. The Seventh Burgess's assertion that he will not meet Jesus without his cohorts (249-50) acknowledges the role of the community in sustaining an individual's faith, for it is only through the community's ability to provide readily believable arguments, despite the absence of necessary demonstration therein, that the person will reach Jesus.

The Eighth Burgess also evaluates his interlocutors' arguments and illustrates the link between verbal rhetoric and the pathos-driven desire to see Jesus firsthand:

3oure argumentis pai are so clere

I can not saie but graunte you till,

For whanne I of pat counsaille here

I coveyte hym with feruent wille

Onys for to see.

Like his counterparts, the Eighth Burgess declares that his fervent desire to see Jesus stems from the sound arguments he has heard and vetted. The arguments themselves instill in him such zeal that he has no choice but to meet Jesus at once. ${ }^{21} \mathrm{He}$ and his cohorts openly assess each other's arguments 
because the playwright is calling attention to the types of arguments and discursive interactions that lead people to Christ. Ironically, the arguments do not exhibit the 'clear reason' that the characters tout, but they are necessary to bringing their participants to Jesus. The burgesses also realize, as the Porter did, the need to present these arguments to the entire community. They take up this charge with vigor, for when they finish deliberating, they resolve that they, along with their children, will 'Go synge before, pat men may knawe / To pis graunte we all' (264-5). By granting their communal assent to their plan of action, the characters highlight the socially contingent nature of communal piety.

The playwright embraces this socially contingent experience by granting the burgesses an awareness of their own roles in constructing arguments for their faith. When the Eighth Burgess evaluates his interlocutors' statements, he calls attention not only to their contingent nature, but also to his and his interlocutors' roles in articulating them. He states:

Sirs methynketh 3e saie right wele
And gud ensampelys furth 3e bring,
And sen we pus pis mater fele
Go we hym meete as oure owne kyng,
And kyng hym call.
What is youre counsaill in pis thyng?
Now say 3e all.

By declaring that his interlocutors' arguments 'seem' ('methynketh') 22 good to him, the burgess acknowledges both the conditional nature of human knowledge and his own agency in granting validity to the arguments. Moreover, the very term he uses to describe the council's deliberations touches upon the creative and rhetorical nature of the burgesses' enterprise. The verb 'fele', meaning 'to discover; inquire into', 23 invokes the rhetorical notion of 'inventio', which Cicero describes as 'the discovery of valid or seemingly valid arguments to render one's cause plausible'. ${ }^{24}$ The knowledge on which the burgesses act seems valid, plausible, and readily believable to them based on the arguments that they have created together. These arguments lead the burgesses to settle upon the title of 'king' for Jesus, a title that they resolve to bestow upon him in person. The playwright thus acknowledges the rhetorical nature of the burgesses' devotion and presents their actions as models for the audience's own. As members of the corporate rhetorical tradition, they must 
acknowledge their roles as rhetors who are to construct arguments that articulate the principles of their faith. The burgesses' calling for further counsel, after naming Jesus their king, only emphasizes the importance of the rhetorical interaction itself: the communal discovery, acceptance, and transmission of the Christian message. ${ }^{25}$

The playwright presents the apotheosis of Christian rhetorical invention in the townspeople's lyrical praising of Jesus at the city gates. ${ }^{26}$ This praise takes the form of an extended anaphora repeating the word 'Hail' at the beginning of each poetic line, with each statement expounding various principles of devotion to Jesus. Within these statements we can see the thematic continuity in the burgesses' speeches before and after Jesus's miracles. After the miraculous spectacle, the burgesses erupt:

Burg. 1:
Hayll prophette preued withouten pere,
Hayll kyng comely, curteyse and clere,
Hayll souerayne semely, to synfull sure;
To the all bowes.
Hayll lord louely oure cares may cure,
Hayll kyng of Jewes.

Burg. 3: $\quad$ Hayll Dauid sone, doughty in dede.

These triumphant lyrics are similar to those proclaimed by the apostles after they meet the risen Christ in the Thomas plays. One might argue, as Scoville convincingly does about the lyrics in those plays, that the burgesses' zealous proclamations are inspired not by a sense of truth reached through their previous deliberations, but by one reached through their 'communal, affective, physical experience [of Christ] as the final source of truth'. ${ }^{27}$ Taken in this regard, verbal interaction is depicted as a preliminary, but ultimately deficient, means of learning about or communicating the tenets of one's faith. Yet the difference in the epistemological potential of verbal and miraculous rhetoric, as each is depicted in this play, is not as great as it would appear to be. Many of the claims the burgesses make after witnessing Jesus's miracles are the same as those made before they see them: Jesus is a great prophet (123, $127,156,489)$; he stems from the line of David (162-8, 503); and he is king of the Jews $(223-5,495)$. The townspeople display equal amounts of faith in Christ's divinity and sovereignty before witnessing his miracles - when 
their deliberations were their only source of truth - as they do after witnessing his miracles. Though the townspeople do not indulge in panegyrics until after the miracles are performed, they have interwoven, in their deliberation throughout the play, epideictic praise that displays their knowledge of his greatness. The playwright is arguing that, for the members of the corporate rhetorical tradition, the certainty of belief that comes from their commonly accepted arguments should anticipate the certainty that will come when they actually meet Jesus face to face in the afterlife. Put another way, the audience members' fervent belief, in this life, in the power of each other's words must be equivalent to the certainty that they will experience when, in the next life, they meet The Word: Christ himself.

I do not, however, wish to argue that Jesus's presence and miracles play inconsequential roles in the playwright's rhetorical and devotional agenda. I propose that the characters' responses to Jesus's presence at the end of the play illustrate the creative and interpretive potential of Christian rhetoric. Jesus's miracles inspire in the crowds an even greater level of rhetorical investment, one in which the speaker preserves his unwavering commitment to his community's verbal affirmation of its faith. The speaker also, however, surpasses the act of merely repeating the messages he has heard already, and creates new arguments to promote the faith of his fellow Christians. The final stanzas show how the townspeople, fortified by their unwavering certainty in Jesus's status, create and explore new metaphorical themes that add to the community's devotion to Christ:

$\begin{array}{ll}\text { Burg. 5: } & \text { Hayll jasper gentill of Jury } \\ & \text { Hayll balme of boote, moyste and drye } \\ & \text { To all has nede. }(518-20) \\ \text { Burg. 7: } & \text { Hayll sonne ay schynand with bright bemes, } \\ & \text { Hayll lampe of liff schall neuere waste, } \\ & \text { Hayll lykand lanterne, luffely lemys, } \\ & \text { Hayll texte of trewpe pe trew to taste. }\end{array}$

Rather than remaining mere transmitters of pre-existing stories, the townspeople become creators of devotional motifs that later speakers may use. By the end of the play Jesus encompasses the gentle beauty of a flower (518), the healing power of an ointment (519), and, using paronomasia to play on his status as the Son of God, the everlasting light of the sun (531). Through this 
creative encomium, the characters fulfill the Porter's earlier vow to provide his listeners with 'novelte', or something 'newe'. The playwright effects this change at the play's climactic ending to show that such poetic and rhetorical 'newness' comes only when the entire community engages in a verbal exploration and celebration of its faith. Through polyptoton, the playwright shows these rhetorical efforts to be constructed through the townspeople's analysis of the 'texte of trewpe pe trew to taste' (534). ${ }^{28}$ The play ultimately presents Jesus's complex and multivalent textuality as itself a source of topoi for further rhetorical invention. ${ }^{29}$ The playwright ends the drama by juxtaposing this notion of Christ as 'text' with the other texts most often cited by the characters: the commonly accepted stories of Christ's life, deeds, and spiritual significance. ${ }^{30}$ The medieval audience would have access to these stories in scripture, the ultimate source of authority and irrefutable proof for Christian rhetors. ${ }^{31}$ By uniting verbal and incarnational proofs at the play's climactic ending, the playwright bestows upon them equal levels of validity and provides his audience with an emotional, socially contingent, and ultimately rhetorical way to interact with its faith.

These rhetorical interactions are, for the metropolitan audience of York, one of the most common means of instilling and sustaining devotion, simply because the audience will not be able to rely upon seeing spectacular miracles performed openly in the city streets. The closest they will come to witnessing such miracles in their quotidian lives will be in their roles as dramatic audience. Zache, a publican viewing the commotion from atop a sycamore tree, accurately characterizes the uniqueness of the situation. ${ }^{32} \mathrm{He}$ states that the tumult surrounding Jesus's entrance and miracles is like nothing he has ever seen:

Sen firste this worlde was made of no3t

And all thyng sette in equité,

Such ferly thyng was neuere non wroght

As men this tyme may see with eye.

(392-5; emphasis mine)

Zache acknowledges that these strange and marvelous ${ }^{33}$ events are unlike any that have occurred since Creation. Particularly significant, though, is his assertion that only 'this tyme may see [such things] with eye' (395; brackets mine). The 'tyme' to which Zache is referring is specifically the time allotted for the dramatic recreation of Jesus's presence and miracles. Even though the play recreates the scene for the medieval audience, the 'ferly' events like Jesus 
himself publicly restoring sight to the blind and movement to the lame are of a spectacular past that, regardless of their spiritual significance, only can be mimicked dramatically. Thus, while allowing the audience to 'witness' the miracles through dramatic presentation, the play also firmly separates the marvelous world of the dramatic action from the mundane world of late medieval York. ${ }^{34}$ Despite the audience's involvement in the dramatic action, it is also aware that the 'miracles' depicted in the play are indeed representations, scripted events performed by actors. In the very act of dramatic representation, the play acknowledges that such events rarely happen in the open streets of a bustling city, for all eyes to verify. Lacking such certain, miraculous proofs, the Christian community must rely on the contingent rhetoric of a shared faith. If, like the burgesses, the audience participates actively and fervently in discovering and communicating the truths of its faith, it too will realize the miraculous power of its own words.

\section{Notes}

1 All quotations from the York 'Entry' are from Richard Beadle (ed.), The York Plays (London, 1982). I wish to thank Cara Baummer, Frederick M. Biggs, Becky Caouette, Rebecca Devers, Joshua R. Eyler, Brandon Hawk, Barbara D. Palmer, Andrew M. Pfrenger, and Sarah Winter for their helpful comments on various drafts of this essay, an earlier version of which was presented at the $43^{\text {rd }}$ International Congress on Medieval Studies, Kalamazoo, MI, 8 May 2008, Session 34, 'Rhetoric and Language in Medieval English Drama'.

2 For convincing arguments that the intra-dramatic 'audience' that witnesses Jesus's entrance should be equated with the extra-dramatic audience of the play itself (and viceversa), see Richard Beadle, 'The York Cycle', The Cambridge Companion to Medieval English Theatre, Richard Beadle (ed) (Cambridge, 1994), 85-108, esp. 87; Sarah Beckwith, Signifying God: Social Relation and Symbolic Act in the York Corpus Christi Plays (Chicago, 2001), 101; and Richard J. Collier, Poetry and Drama in the York Corpus Christi Play (Hamden, 1978), 18, 198. For explorations of the religious and political significance of the burgesses' verbal interactions see Ruth Nisse, Defining Acts: Drama and the Politics of Interpretation in Late Medieval England (Notre Dame, 2005), 30-9; and Rosemary Woolf, The English Mystery Plays (Berkeley, 1972), 233. For a new study concerning the York audience's 'active engagement of sacred playing', see Heather Hill-Vásquez, 'Devotional Response and Responsibility in the York Cycle', Sacred Players: The Politics of Response in the Middle English Religious Drama 
(Washington, DC, 2007), 102-21, 104. On the paradigms of devotional and civic procession that influenced the play's structure, see Martin Stevens, Four Middle English Mystery Cycles: Textual, Contextual, and Critical Interpretations (Princeton, 1987), 50-3; and Gordon Kipling, Enter the King: Theatre, Liturgy, and Ritual in the Medieval Civic Triumph (Oxford, 1998), 6. On possible staging scenarios see Pamela King, The York Mystery Cycle and the Worship of the City, Westfield Medieval Studies vol 1 (Woodbridge, 2006), 137-42; Barbara D. Palmer, 'Gestures of Greeting: Annunciations, Sacred and Secular', Gesture in Medieval Drama and Art, Clifford Davidson (ed.) (Kalamazoo, 2001), 128-57; Martin Stevens, Four Middle English Mystery Cycles, 60-2; and Alexandra F. Johnston, 'The York Corpus Christi Play: A Dramatic Structure Based on Performance Practice', Herman Braet, Johan Nowe, and Gilbert Tournoy (eds), The Theatre in the Middle Ages (Leuven, 1985), 362-73.

3 For Aristotle's treatment of epideictic rhetoric, the rhetoric of praise or blame, see $O n$ Rhetoric: A Theory of Civic Discourse, trans. George A. Kennedy (New York, 1991), 1.3-6. All subsequent references to Aristotle will be from this edition, cited by book, chapter, and paragraph number.

4 The York 'Entry' depicts lyrical responses to the miraculous that are quite similar to those in the biblical plays of Thomas, in which Chester Scoville, in Saints and Audience in Middle English Biblical Drama (Toronto, 2004), identifies, in the miraculous presence of the risen Christ, 'an incarnational kind of rhetoric: one based upon a pathetic response to apodeictic proof of corporeality' (28). In the Thomas plays, Scoville argues, 'it is precisely the wonder of a miracle that engages Thomas, and the plays as a whole, to move into the panegyric mode, in which an audience's passions are directly engaged' (ibid). In contrast, the York 'Entry' depicts characters constantly engaging in epideictic praise of Jesus. For a greater part of the play there are no miracles, and only the characters' deliberative rhetoric provides the evidence and inspiration for their praise.

5 Scoville explores in the Thomas plays the inadequacy of verbal argument when compared to the highly persuasive nature of 'the physicality of Christ ... as a species of proof' (ibid, 12). The plays, Scoville argues, 'set limits on the power of rhetoric in the realm of faith ... [and] explore the limitations of human language and the functions thereof' (ibid). He concludes that, when trying to understand the concept of Christ's bodily resurrection, 'argument does not work; the eloquent body of Christ itself is the only possible proof' (ibid, 22). While Scoville's insightful analysis sheds light on the Thomas plays of various cycles, I intend to show that the York 'Entry' depicts a situation in which verbal rhetoric, including verbal accounts of Christ's miracles, is the primary means through which people come to understand their faith.

'Metatheatricality on the Medieval Stage', Mediaevalia 18 (1995), 394. 
7 The Chester cycle and N-Town compilation also contain plays that depict Jesus's entrance into Jerusalem. Neither play's characters so overtly emphasize each other's arguments as do those in the York play. See 'Play XIV: The Corvisors Playe', R.M. Lumiansky and David Mills (eds), The Chester Mystery Cycle, 2 vols, Early English Text Society ss 3 and 9 (London, 1974, 1986), and 'Play 26: Prologues of Satan and John the Baptist; The Conspiracy; The Entry Into Jerusalem', Stephen Spector (ed.), The N-Town Play: Cotton MS Vespasian D.8, 2 vols, Early English Text Society ss 11 and 12 (Oxford, 1991), 11. 343-485.

8 Augustine of Hippo argues that creation itself is miraculous: 'the whole universe is full of wonders which seem to us hardly worth noticing or examining, not because they are easily penetrated by our reason, but because we are accustomed to seeing them. But I ... wonder neither more nor less at the fact that in one tiny seed all that we praise in the tree lies folded away, than that the great bosom of the earth will restore whole and entire, at the future resurrection, all that it consumes of human bodies when they fall into decay'; see 'Letter 102: To Deogratias [Six Questions Answered for Pagans]', Sister Wilfrid Parsons, snd (trans.), Letters, vol. 2, 81-180 (Washington, DC, 1953), 148-77, 151. Cf. Jacques-Paul Migne's Patrologia Latina (1844-1855 and 1862-1865), Patrologia Latina Database vol. 33, col 372 (hereafter cited as PL, followed by volume and column number), ProQuest, Homer Babbidge Lib., U of Connecticut, Storrs Cт. 22 June 2008. <http://gateway.proquest.com/openurl?url_ ver=Z39.88-2004\&res_dat=xri:pld-us\&rft_dat=xri:pld:ft:all:Z500060210>. See also Benedicta Ward, Miracles and the Medieval Mind: Theory, Record, and Event, 10001215 (Philadelphia, 1982), 3-19, esp. 3, 13.

9 Beckwith observes the tendency of the drama to emphasize, rather than eliminate, the distance between the world of the play's audience and the world of the biblical narrative. Concerning the medieval audience's need to see miracles enacted, she states: '[T] he very necessity to see what you believe is a testimony to the doubt which underlies the implicit logic of the miracle play. And the play can do nothing but intensify that doubt in the very act of alleviating it. For the miracle in a miracle play is a purely theatrical event'; see 'Ritual, Church and Theatre: Medieval Dramas of the Sacramental Body', David Aers (ed.), Culture and History 1350-1600: Essays on English Communities, Identities and Writing (Detroit, 1992), 68. For the importance of the faculty of eyesight to the York 'Entry', see Barbara I. Gusick, 'Groping in the Darkness: The Man Born Blind and Christ's Ministry in the York Cycle', Barbara I. Gusick and Edelgard E. DuBruck (eds), New Approaches to European Theater of the Middle Ages: An Ontology, (New York, 2004), 45-6.

10 Boethius, one of the most influential sources of medieval rhetorical theory, states, 'Something is readily believable ['probabile vero'] if it seems true to everyone or to 
most people or to the wise - and of the wise, either to all of them or most of them ... or, finally, if it seems true to the person with whom one is having the conversation or who is judging it. In this, the truth or falsity of the argument makes no difference, if only it has the appearance of truth. Something is necessary ['necessarium vero'] if it is as it is said to be and cannot be otherwise'; see Eleonore Stump (trans.), Boethius's De Topicis Differentiis, (Ithaca and London, 1978), 39. All English translations will be from this volume, cited by page number. Stump's textual notes are instrumental to my characterization of these two types of argument (ibid, 109n81). See also PL vol. 64, col. 1180C, D, ProQuest, Homer Babbidge Lib., U of Connecticut, Storrs Ст. 19 Jan. 2009. <http://gateway.proquest.com/openurl?url_ver=Z39.882004\&res_dat=xri:pld-us\&rft_dat=xri:pld:ft:all:Z400035666>.

11 Boethius describes an enthymeme as 'an imperfect syllogism, that is, discourse in which the precipitous conclusion is derived without all the propositions having been laid down beforehand ... it is, as it were, similar to a syllogism; but because it does not use all the propositions appropriate to a syllogism, it deviates from the definition (ratio) of a syllogism and so is called an imperfect syllogism' (De Topicis Differentiis, 45; parentheses in original). Aristotle, who labeled the enthymeme a 'rhetorical syllogism', observed the following about its reliance on uncertain judgement or opinion, rather than fact: "few of the premises from which rhetorical syllogisms are formed are necessarily true (most of the matters with which judgement and examination are concerned can be other than they are; ... )' (On Rhetoric, 1.2.14; parentheses in original). For more on the relationship between 'commonly held opinion' and the enthymeme, see 1.1.10-14.

12 Murphy, Rhetoric in the Middle Ages: A History of Rhetorical Theory from Saint Augustine to the Renaissance (Berkeley, 2001), 273.

13 rēsǒun $n$. (2) 2(d), H. Kurath, et al. (eds), Middle English Dictionary (MED), (Ann Arbor, 1952-2001). Cited from the electronic version in Frances McSparran, et al. (eds), The Middle English Compendium, (Ann Arbor, 2001), 23 June 2008. <http:// quod.lib.umich.edu/cgi/m/mec/med-idx?type=id\&id=MED37106>.

14 trusten $v$. 1(c), electronic MED, 22 June 2008. <http://quod.lib.umich.edu/cgi/m/ $\mathrm{mec} / \mathrm{med}$-idx?size=First+100\&type=headword \&q1=trusten \&rgxp=constrained $>$.

15 Boethius, De Topicis Differentiis, 40.

16 In neither the Chester nor the N-Town accounts does the donkey's caretaker demand a 'reason' for the apostles' taking of the beast. The N-Town Burgess demands that the apostles tell him 'who 3aff 3ow leve / Thus pis best for to take away?' (N.26.360-1), while the Chester Janitor states that he will not let the apostles make off with the beast (and its foal, in this instance) 'but thou tell me or thou passe / whither they shall 
go' (C.14.155-6). Within English medieval drama the apostles' 'reason' for taking the donkey is, to my knowledge, a concern unique to the York playwright.

17 Murphy, Rhetoric in the Middle Ages, 290.

18 Claire Sponsler reminds us, however, that the medieval audience did not necessarily fall in lock-step with the intent of the playwright(s) or producers. She states that we should not assume that the audience would have agreed on any but the most basic principles of Christianity: 'For any audience, beyond agreement on the basic elements of the performance — that Christ has been crucified, or that Noah's family has been saved from the flood - and even that basic agreement may sometimes be lacking, the meaning of the play cannot be invariably fixed', in 'The Culture of the Spectator: Conformity and Resistance to Medieval Performances', Theatre Journal 44.1 (1992), 28. While we should heed Sponsler's point about the myriad interpretations of any performance, we may assume that the stories recounted by the play's characters would be immediately recognizable as commonly accepted truths of Christianity.

19 John 20:29, The Holy Bible: Douay-Rhimes Version, Challoner Revision, Old and New Testaments (Champagne, 1998 [Etext \#1581]), Net Library, Homer Babbidge Lib., U of Connecticut, Storrs, CT. <https://vpn.uconn.edu/Reader/,DanaInfo=www.netlibrary.com+>.

20 wit $n$. 2(a), electronic MED, 23 June 2008. <http://quod.lib.umich.edu/cgi/m/mec/ med-idx?type=id\&id=MED52981>.

21 The citizens of the Chester play also refer to 'proof' of Jesus's divinity, but they cite only his miracles, and not each other's arguments, as reasons to welcome him. See esp. 11. 197-9: 'These miracles preeven appertlye / that from the Father almightie / hee is commen'. The four citizens of the N-Town play do not deliberate at all. Rather, the playwright assigns each character a couplet that articulates a single premise of a larger argument for welcoming Jesus (442-9). By assigning portions of a single argument to several characters, the N-Town playwright illustrates the corporate rhetorical tradition in a compressed and highly effective manner.

22 thinken $v$. (1) 7(b), electronic MED, 23 June 2008. <http://quod.lib.umich.edu/ $\mathrm{cgi} / \mathrm{m} / \mathrm{mec} / \mathrm{med}-\mathrm{idx}$ ?type $=\mathrm{id} \& \mathrm{id}=\mathrm{MED} 45309>$.

23 Beadle, 'Glossary', The York Plays, 492.

24 Cicero, De Inventione, 1.9.

25 Here my argument differs from a recent analysis by Nisse, who argues that the playwright employs the burgesses to argue for 'the distinct vocabulary of civic government as the basis of its scriptural interpretation' (Defining Acts, 33). While I agree that the burgesses' deliberation of Jesus's qualities as the messiah invokes 'the principles of rule by ancient tradition and consensus' (33), I disagree with the assertion that the burgesses employ the language of the civic sphere in order to 'present their 
case for secular authority over Scripture and, in the process, translate the vocabulary of urban government into a method of exegesis' (36). The burgesses' deliberation is merely part of a larger rhetorical framework that includes the apostles, a workman like the Porter, and such socially marginal figures as the blind man Cecus, the lame man Claudus, and the usurious publican Zacheus.

26 Eamon Duffy, The Stripping of the Altars: Traditional Religion in England 1400-1580, 2nd ed. (New Haven, 2005), notes that the speeches of praise and welcome at the end of the play are most likely based on the lyrics sung at the elevation of the Host during the Corpus Christi procession (27); see also Pamela King, The York Mystery Cycle and the Worship of the City, Westfield Medieval Studies vol 1 (Woodbridge, 2006), $140-1$.

27 Scoville, Saints and Audience, 10; brackets mine.

28 For a fascinating analysis of medieval women's notion of Jesus as 'food', which the devout could 'taste' (534), see Caroline Walker Bynum, Holy Feast and Holy Fast: The Religious Significance of Food to Medieval Women (Berkeley, 1987).

29 Previous scholarship has argued that many biblical plays present rhetorical invention in a negative light, where rhetorical complexity is espoused by either ranting tyrants or duplicitous counselors. See, for example, Elza C. Tiner's informative 'Classical Invention in the York Trial Plays,' Florilegium 8 (1986),199-211. On the obfuscating potential of rhetorical or poetic complexity in matters of faith, see Stevens, Four Middle English Mystery Cycles, 161. In a more recent study, Douglas W. Hayes, in Rhetorical Subversion in Early English Drama, Studies in the Humanities LiteraturePolitics-Society, vol. 64 (New York, 2004), explores rhetoric's role as a 'morally moldable medium of communication' (3). For an early discussion of topoi, see Cicero's Topica: 'Similarly, if we wish to track down some argument we ought to know the places or topics: for that is the name given by Aristotle to the "regions", as it were, from which arguments are drawn. Accordingly, we may define a topic as the region of an argument'; see H M. Hubbell (trans.), De Inventione, De Optimo Genere Oratorum, Topica (Cambridge, 1949) 1.8.

30 The notion of Christ as 'text' evokes the affective tradition in which the devout, while meditating upon Christ's wounds, would contemplate his sacrifice for humanity. This meditation would then lead to a greater emotional connection with Christ's suffering, and allow the believer to comprehend God's mercy, which mankind does not deserve. See Eleanore Prosser, Drama and Religion in the English Mystery Plays (Stanford, 1961), 31. Cf. Frederick Christian Bauerschmidt, 'Seeing Jesus: Julian of Norwich and the Text of Christ's Body', Journal of Medieval and Early Modern Studies 27.2 (1997), 189-214, esp. 190.

31 Murphy, Rhetoric in the Middle Ages, 277. 
32 The story of Zacheus is adapted from Lk 19:1-10.

33 ferlī adj. 1(b), electronic MED, 22 June 2008. <http://quod.lib.umich.edu/cgi/m/ $\mathrm{mec} / \mathrm{med}$-idx?type=id\&id=MED15693>.

34 In an intriguing essay that encourages critics to examine the relationship between miraculous events and their social consequences, Gusick suggests that the York 'Entry' prompts its audience to explore the 'redefined' social roles of the newly healed body, which must be integrated into society: see 'Christ's Healing of the Lame Man in the York Cycle's "Entry into Jerusalem": Interpretive Challenges for the Newly Healed', Fifteenth-Century Studies 31 (2006), 87. For an article in a similar vein, concerning Zacheus's prospects for social reintegration after his renunciation of usury, see Gusick's 'Christ's Transformations of Zacchaeus in the York Cycle's Entry into Jerusalem', Fifteenth-Century Studies 30 (2005), 68-94. See also Gusick's 'Groping in the Darkness', passim. 
